\title{
Klaus Unsicker: in honor of his seventieth birthday
}

\section{H.-W. Korf}

Received: 3 November 2011 / Accepted: 3 November 2011

(C) Springer-Verlag 2011

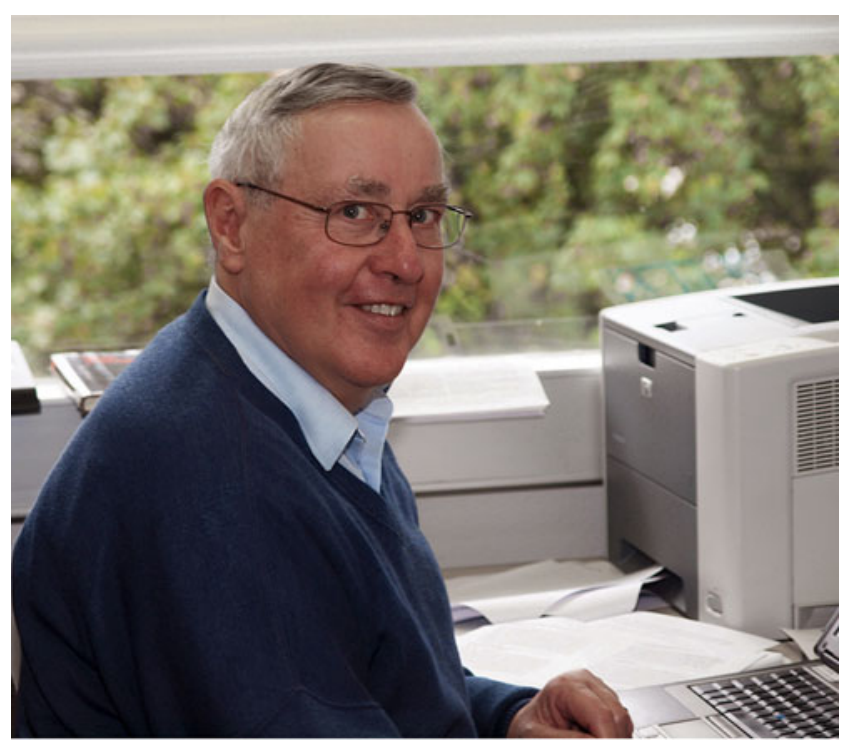

Klaus Unsicker (Fig. 1), who has served as Coordinating Editor of Cell and Tissue Research since 1996, will turn 70 on 3 January 2012. The editors of CTR, Springer-Verlag and his numerous friends and colleagues all over the world would like to congratulate him on this occasion and wish him health and vitality for many years to come.

All of us know Klaus Unsicker as a dynamic and influential scientist for whom science and research seem to be an anti-aging factor. Throughout his career, he has been and has remained young. While still studying medicine at the University of Kiel, Klaus Unsicker had already started

H.-W. Korf $(\bowtie)$

Universitat Frankfurt, Dr. Senckenbergische Anatomie,

Frankfurt, Germany

e-mail: korf@em.uni-frankfurt.de his research activities in the Department of Anatomy headed by Professor Wolfgang Bargmann, world-famous poineer in neuroendocrinology and highly respected editor of this journal for nearly three decades, from 1949 to 1978. Klaus Unsicker was 26 when he completed his doctoral thesis on ganglion cells in the adrenal medulla, and he had just turned 31 when he received the "Habilitation" for Anatomy from the University of Kiel. At the age of 35, he was offered the position as full professor from the University of Munich. Just one year later, Klaus Unsicker took over a position as full professor of anatomy and cell biology at the Philips-University of Marburg which he kept for 14 years. In 1992, he moved to the University of Heidelberg as full professor of anatomy and cell biology, and in 2000 he co-founded the Interdisciplinary Center for Neuroscience in Heidelberg and became its director. After his retirement in 2009, he moved to the University of Freiburg where he continues his research as Visiting Professor in the Department of Molecular Embryology headed by his wife Kerstin Krieglstein who entered the field of anatomy and neurobiology in 1992.

The rich scientific opus of Klaus Unsicker focuses on important and relevant neurobiological questions and is characterized by successful attempts to elucidate mechanisms and factors underlying neural development, differentiation and regeneration. Of outstanding international reputation are his pioneering studies on the development of the adrenal medulla and its preganglionic sympathetic innervation as well as the interactions between adrenal medulla and cortex, but his research on development, survival and proliferation of neurons and astroglial cells in the central nervous system has yielded results of equal significance. Because of his scientific excellence, Klaus Unsicker has been granted support for his research projects by the Deutsche Forschungsgemeinschaft 
(DFG), the major and most competitive funding agency in Germany, from the very beginning of his career until today. Most of his projects have been embedded in major research consortia which were often initiated and driven forward by Klaus Unsicker himself.

The reputation of Klaus Unsicker is also reflected by several honors and prizes of which only a few should be mentioned: Klaus Unsicker was elected as member of the German National Academy of Sciences Leopoldina in 1992, received the Max Planck Research Award in 1997, was awarded the Aschoff Medal of the Medical Faculty in Freiburg in 2001, and an honorary doctorate of his former faculty in Marburg in 2003.

Although original research has been and continues to be his genuine goal, Klaus Unsicker has served the scientific community with various other activities. He was president of the Anatomische Gesellschaft from 1994 to 1995 and of the International Society for Developmental Neuroscience from 1998 to 2000. Since 2004, he has chaired the Neuroscience Panel of the Deutsche Forschungsgemeinschaft which evaluates all applications in neuroscience from Germany. Last but not least, Klaus Unsicker has devoted a considerable portion of his time to Cell and Tissue Research since he took over the position as coordinating editor from Andreas Oksche in 1996. Ever since, Klaus Unsicker has constantly sought to maintain and improve the quality and the impact of our journal. Upon his initiative, the journal has published with great success several special issues, reviews and minireviews reflecting the multifaceted progress in molecular, cell and supracellular biology.

Together with many colleagues all over the world, we thank Klaus Unsicker for his constructive advice and continuing support. Ad multos annos!

Horst-Werner Korf, Section Editor 